\title{
Micronutrient (Cu, Zn, Fe and Mn) Uptake in Soybean [Glycine max (L.) Merill] Growing Soils of Dharwad Taluk (Karnataka)
}

\section{B. Chandra Sheker ${ }^{1 *}$, B.M. Radder ${ }^{1}$, Vijay Kumar Didal' ${ }^{2}$, Badaka Amruth ${ }^{3}$ and Arigela Kiran ${ }^{4}$}

\author{
${ }^{1}$ Department of Soil Science and Agricultural Chemistry, ${ }^{2}$ Department of Agronomy, College of \\ Agriculture, University of Agricultural Sciences, Dharwad (Karnataka) - 580005, India \\ ${ }^{3}$ Department of Soil Science and Agricultural Chemistry, University of Agricultural and \\ Horticultural Sciences, Shivamogga (Karnataka), India \\ ${ }^{4}$ Department of Soil Science and Agricultural Chemistry, University of Mahatma Phule Krishi \\ Vidyapeeth, Rahuri, (Mahrastra), India \\ *Corresponding author
}

\section{A B S T R A C T}

The present investigation was carried out to study the uptake of micronutrients in soybean growing soils of Dharwad taluk during 2015-16 kharif season. For this purpose 51

\begin{tabular}{|l|}
\hline Ke y w or d s \\
$\mathrm{Cu}, \mathrm{Zn}, \mathrm{Fe}$ and \\
$\mathrm{Mn}$, Soybean, \\
Nutrient uptake. \\
\hline Article Info \\
\hline Accepted: \\
04 June 2017 \\
Available Online: \\
10 July 2017 \\
\hline
\end{tabular}
representative soybean growing soils of Dharwad taluk were selected. Based on the average grain yields in 51 fields, the entire group was divided into below average and above average yield categories. Mean yield of 51 fields was $14.67 \mathrm{q} \mathrm{ha}^{-1}$. Crop cutting experiment from the selected farmers' fields were carried out for recording yield data. The study revealed that micronutrient uptake in below average yield category ranged from 45.01 to $68.44 \mathrm{~g} \mathrm{ha}^{-1}$ with a mean value of $55.90 \mathrm{~g} \mathrm{ha}^{-1}, 84.28$ to $108.05 \mathrm{~g} \mathrm{ha}^{-1}$ with a mean value of $99.49 \mathrm{~g} \mathrm{ha}^{-1}, 490.72$ to $690.61 \mathrm{~g} \mathrm{ha}^{-1}$ with a mean value of $643.28 \mathrm{~g} \mathrm{ha}^{-1}$ and 91.26 to $140.74 \mathrm{~g} \mathrm{ha}^{-1}$ with a mean value of $118.67 \mathrm{~g} \mathrm{ha}^{-1}$ of $\mathrm{Cu}, \mathrm{Zn}, \mathrm{Fe}$ and $\mathrm{Mn}$ respectively. The micronutrient uptake in above average yield category ranged from 56.24 to $78.85 \mathrm{~g} \mathrm{ha}^{-1}$ with a mean value of $68.72 \mathrm{~g} \mathrm{ha}^{-1}, 113.45$ to $141.14 \mathrm{~g} \mathrm{ha}^{-1}$ with a mean value of $128.68 \mathrm{~g}$ $\mathrm{ha}^{-1}, 718.33$ to $874.25 \mathrm{~g} \mathrm{ha}^{-1}$ with a mean value of $795.61 \mathrm{~g} \mathrm{ha}^{-1}$ and 104.14 to $162.16 \mathrm{~g} \mathrm{ha}^{-1}$ with a mean value of $134.25 \mathrm{~g} \mathrm{ha}^{-1}$ of $\mathrm{Cu}, \mathrm{Zn}, \mathrm{Fe}$ and $\mathrm{Mn}$ respectively. Among micro nutrients, available zinc and iron were found to be positively and significantly correlated with dry matter production in both below average and above average yield categories.

\section{Introduction}

Soybean [Glycine max (L.) Merill], being the "Golden Bean", of the $20^{\text {th }}$ century is a species of legume, native to East Asia, widely grown for its edible bean which has numerous uses. Soybean is described variously as a "miracle bean", "crop of the planet", "God sent golden bean" and "greater bean," etc. The plant is classed as an oilseed rather than a legume by the Food and Agricultural
Organization (FAO). Soybean is one of the nature's most versatile and fascinating crop in the present farming system of Indian agriculture. An increase in population pressure increased the demand of edible oil greatly in last decade. As a result there is an increase in the area of oil seed crops in the country. Among the oil seed crops, Soybean is largely popularized in recent years in the 
country as well as in Karnataka. It also enriches the soil through symbiotic $\mathrm{N}$-fixation and its residual nitrogen is about $30-40 \mathrm{~kg} \mathrm{~N}$ per hectare for succeeding crops (Apeji, 1988). The soybean contains high protein (40$43 \%$ ), oil content (24-26\%) and also consists of high percentage of amino acids which are essential in human nutrition. Its oil content belongs to the linolenic unsaturated fatty acid group without cholesterol. Fat-free (defatted) soybean meal is a significant and cheap source of protein for animal feeds and many pre-packaged meals. In addition to this, soybean protein has five per cent lysine, which is deficient in most of the cereals and enriching the cereal flour with soybean improves the nutritive quality.

In India, major soybean producing states are Madhya Pradesh, Uttar Pradesh, Rajasthan, Gujarat, Maharashtra, Andhra Pradesh and Karnataka. Karnataka is one of the major soybean growing state occupying about 2.470 lakh ha with an annual production of 3.001 lakh MT with the productivity of $1215 \mathrm{~kg} \mathrm{ha}^{-1}$ (Anonymous, 2014).

Being an easy care crop, it is widely acceptable by majority of farmers and it gets its preference for all type of soils (Jagdish and Hajare, 1992). Introduction of soybean has led to a shift in the cropping system from fallow-wheat/ chickpea to soybeanwheat/chickpea system (Jagdish and Singh, 1997). Soybean being oilseed legume besides phosphorus and sulphur some of the micronutrients like $\mathrm{Zn}, \mathrm{Fe}, \mathrm{Mn}$ and $\mathrm{Cu}$ are required to improve and sustain performance of the soybean crop. Zinc promotes growth hormones, starch formation, seed maturation and production of plant whereas, iron helps in the absorption of other nutrient, Fe and $\mathrm{Mn}$ play an important role in chlorophyll formation and copper has some indirect effect on nodule formation.
Metals such as Zinc, iron and manganese have vital roles in plant's life cycle and very important for normal growth plants (Fageria, 2007). Zinc is considered as the most limiting factor in producing crops in different parts of the world (Mandal et al., 2000; Fageria and Baligar, 2005). $\mathrm{Zn}$ is an essential catalytic component of over 300 enzymes, including alkaline phosphatase, alcohol dehydrogenase, $\mathrm{Cu}-\mathrm{Zn}$ superoxide dismutase, and carbonic anhydrase (Fox and Guerinot, 1998). Zinc plays an important role in synthesizing proteins, RNA, DNA and precursor of auxin which is essential for cell elongation (Welch, 2001; Awlad et al., 2003).

Iron plays an important role in nitrogen fixation and photosynthesis (Bennett, 1993). Synthesis of chlorophyll, thylakoid, and many ferrous proteins is dependent on this element (Imsande, 1998). Iron deficiency in plants is caused by factors that either inhibit its absorption and translocation or impair its utilization in metabolic processes (Fontes and Cox, 1998).

Manganese is an essential element for plants growth and is identified a co- factor for nitrogen catabolism in leaves and a major factor for stabilizing nitrogen within roots and its transfer to shoots in soybean (IzaguirreMayoral and Sinclair, 2005). Mn plays an important role in stabilization of structural protein, the ultra-structural of chloroplasts' and photosynthesis (Popelkova et al., 2003).

\section{Materials and Methods}

\section{Location of the study area}

The study area is Dharwad taluk in Dharwad district, Karnataka. The study area lies between $15^{\circ} 21^{\prime}$ to $15^{\circ} 31^{\prime} \mathrm{N}$ latitude and $74^{\circ}$ $48^{\prime}$ to $75^{\circ} 9^{\prime} \mathrm{E}$ longitude. The location of study the area is presented in figure 1 . The study area is situated in Northern Transitional 
Zone (Zone-8) of North Karnataka. The location of soil samples in selected villages of Dharwad taluk are presented in figure 2 . The area receives a mean annual rainfall of 716.2 $\mathrm{mm}$.

\section{Preparation of plant sample}

The five plant samples collected for estimating the dry matter production and nutrient uptake from each field at peak flowering stage (55-60 DAS), samples were thoroughly washed with distilled water and dried in hot air oven at $65^{\circ} \mathrm{C}$. Dried samples were powdered in a Willey mill to considerable fineness before storing them in polythene bags for further analysis.

\section{Digestion of plant samples}

Powdered plant samples were treated with concentrated $\mathrm{HNO}_{3}$ overnight for pre digestion. Then, the pre-digested samples were treated with a di-acid mixture $\left(\mathrm{HNO}_{3}: \mathrm{HClO}_{4}\right)(10: 4)$ and digested on a sand bath till colourless white precipitate was obtained. The residue was dissolved in $6 \mathrm{~N}$ $\mathrm{HCl}$, filtered and then the content was made to a known volume by using $6 \mathrm{~N} \mathrm{HCl}$. This digest was used for further nutrient analysis. Zinc, iron, copper and manganese were estimated in the aliquot of di-acid digested plant extract using Atomic Absorption Spectrophotometer (AAS, Shimadzu model) as described by Tandon, 1998.

\section{Nutrient uptake studies}

The micro nutrient uptake by soybean at flowering was worked out using the following equation.

Micro nutrientuptake $\left(\mathrm{g} \mathrm{ha}^{-1}\right)=$ Nutrient content $(\mathrm{ppm}) \times$ Dry matter yield $\left(\mathrm{kg} \mathrm{ha}^{-1}\right)$
Crop cutting experiment on the fields of selected farmers

Crop cutting experiment from the selected farmers' fields were carried out. In each of the fields at the time of harvest in area of $3 \times 3 \mathrm{~m}$ was selected randomly at three different spots. Plants were uprooted in the selected area and pods were separated from plants, yields were recorded by taking average from all the three spots and expressed in quintals per hectare. Average grain yield of these fifty one fields was calculated. Based on this average grain yield, these fifty one fields were divided into below average yield category and above average yield category.

\section{Results and Discussion}

\section{Nutrient uptake studies}

\section{Copper $(\mathrm{Cu})$ uptake}

The copper uptake by soybean plants in below average yield category ranged from 45.01 to $68.44 \mathrm{~g} \mathrm{ha}^{-1}$ with a mean value of $55.90 \mathrm{~g} \mathrm{ha}^{-1}$ and standard deviation of 6.746 (Table 1). In above average yield category it ranged from 56.24 to $78.84 \mathrm{~g} \mathrm{ha}^{-1}$ with a mean value of $68.72 \mathrm{~g} \mathrm{ha}^{-1}$ and standard deviation of 6.604 (Table 1). The mean copper uptake by soybean plants in the above average yield category was found to be higher (Table 1) than that of below average yield category (Table 1) despite similar mean available copper contents in soils of both the categories. This difference is explained by higher organic matter content in the soils of above average yield category that enhanced the availability of native micronutrient cations through the transformation of solid phase to soluble metal complexes. Further, the extensive root system enhanced the copper uptake in such soils. Bidari (2000) reported higher copper uptake by plants grown on soils with high organic matter content. 


\section{Zinc (Zn) uptake}

The zinc uptake by soybean plants in below average yield category ranged from 84.27 to $108.04 \mathrm{~g} \mathrm{ha}^{-1}$ with a mean value of $99.49 \mathrm{~g} \mathrm{ha}^{-}$ ${ }^{1}$ and standard deviation of 6.463 (Table 1). In above average yield category, it ranged from 113.44 to $141.14 \mathrm{~g} \mathrm{ha}^{-1}$ with a mean value of $128.68 \mathrm{~g} \mathrm{ha}^{-1}$ and standard deviation of 7.240
(Table 1). The mean zinc uptake by soybean plants in the below average yield category was found to be lower (Table 1) than that of above average yield category (Table 1). Similar findings were reported by Prasad $e t$ al., (1982). However, it was noticed that there was higher uptake of iron by soybean of above average yield category.

Table.1 Uptake $\left(\mathrm{g} \mathrm{ha}^{-1}\right)$ of micronutrients by soybean crop at flowering stage in Below and above average yield category

\begin{tabular}{|c|c|c|c|c|}
\hline & Copper & Zinc & Iron & Manganese \\
\hline \multicolumn{5}{|c|}{ Below average yield category } \\
\hline Minimum & 45.01 & 84.28 & 490.72 & 91.26 \\
\hline Maximum & 68.44 & 108.05 & 690.61 & 140.74 \\
\hline Mean & 55.90 & 99.49 & 643.28 & 118.67 \\
\hline Standard deviation & 6.746 & 6.463 & 58.046 & 15.288 \\
\hline \multicolumn{5}{|c|}{ Above average yield category } \\
\hline Minimum & 56.24 & 113.45 & 718.33 & 104.14 \\
\hline Maximum & 78.85 & 141.14 & 874.25 & 162.16 \\
\hline Mean & 68.72 & 128.68 & 795.61 & 134.25 \\
\hline Standard deviation & 6.604 & 7.240 & 43.949 & 19.552 \\
\hline
\end{tabular}

Note: Average yield - $14.67 \mathrm{q}$ ha $^{-1}$

Table.2 Correlation coefficients between soil properties and nutrient status with Soybean dry matter production $\left(\mathrm{g}\right.$ plant ${ }^{-1}$ )

\begin{tabular}{|c|c|c|c|c|c|c|c|c|c|}
\hline & Dry matter & $\mathbf{p H}$ & $\mathbf{E C}$ & $\mathbf{O C}$ & $\mathbf{C a C O}_{3}$ & $\mathbf{C u}$ & $\mathbf{Z n}$ & $\mathbf{F e}$ & $\mathbf{M n}$ \\
\hline $\begin{array}{c}\text { Dry } \\
\text { matter }\end{array}$ & 1 & & & & & & & & \\
\hline $\mathbf{p H}$ & -0.128 & 1 & & & & & & & \\
\hline $\mathbf{E C}$ & -0.010 & $0.303^{*}$ & 1 & & & & & & \\
\hline $\mathbf{O C}$ & $0.808^{* *}$ & -0.146 & -0.109 & 1 & & & & & \\
\hline $\mathbf{C a C O}_{3}$ & -0.203 & $0.908^{* *}$ & $0.425^{* *}$ & -0.226 & 1 & & & & \\
\hline $\mathbf{C u}$ & 0.001 & -0.031 & $0.334^{*}$ & -0.141 & -0.010 & 1 & & & \\
\hline $\mathbf{Z n}$ & $0.729^{* *}$ & -0.254 & -0.001 & $0.664^{* *}$ & -0.258 & -0.018 & 1 & & \\
\hline $\mathbf{F e}$ & $0.370^{* *}$ & 0.264 & 0.197 & $0.375^{* *}$ & 0.233 & -0.074 & 0.140 & 1 & \\
\hline $\mathbf{M n}$ & 0.015 & 0.150 & -0.215 & -0.002 & 0.064 & -0.111 & -0.054 & 0.089 & 1 \\
\hline
\end{tabular}

**. Correlation is significant at the 0.01 level

*. Correlation is significant at the 0.05 level 
Fig.1 Location of study area

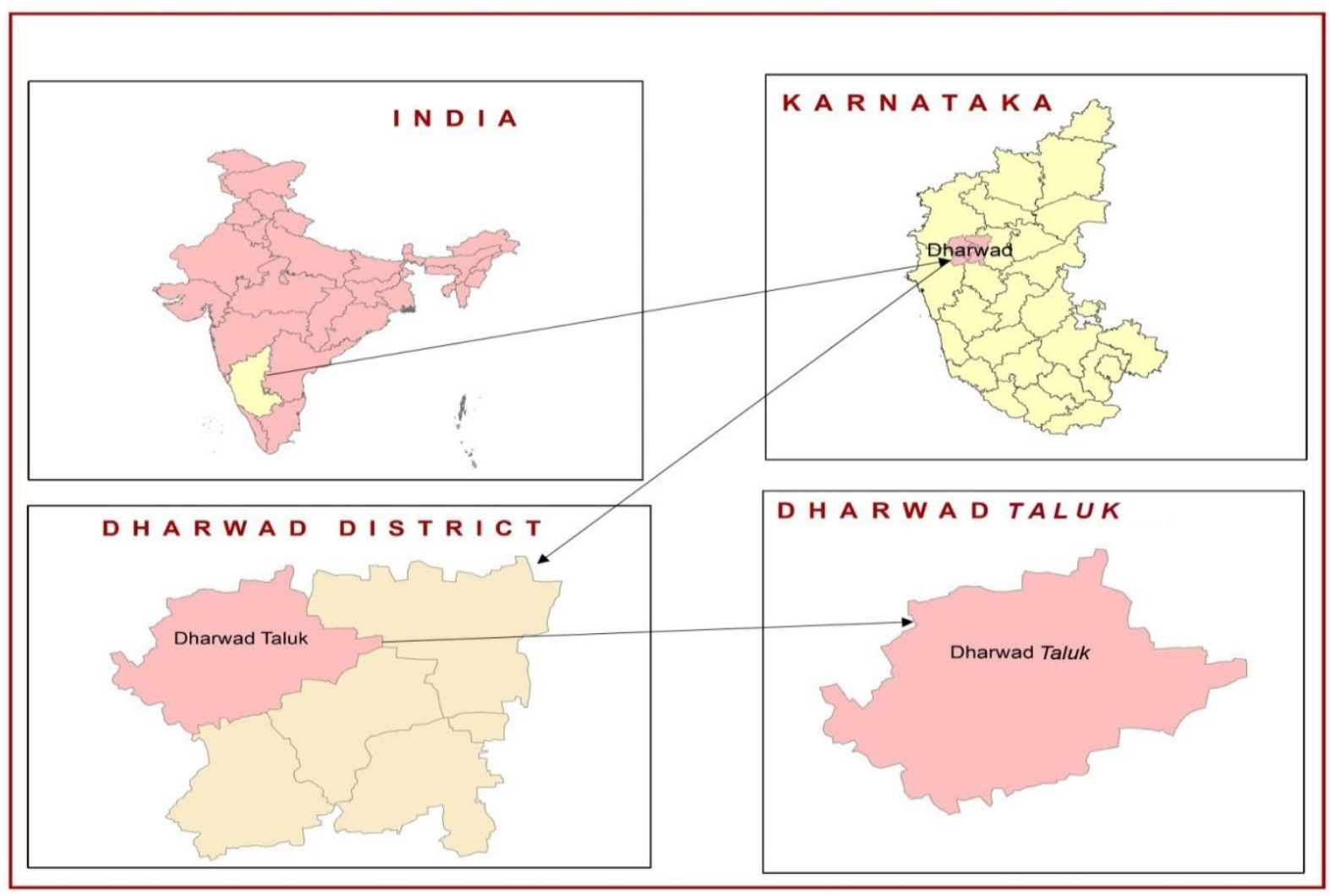

Fig.2 Location of soil samples in Dharwad taluk

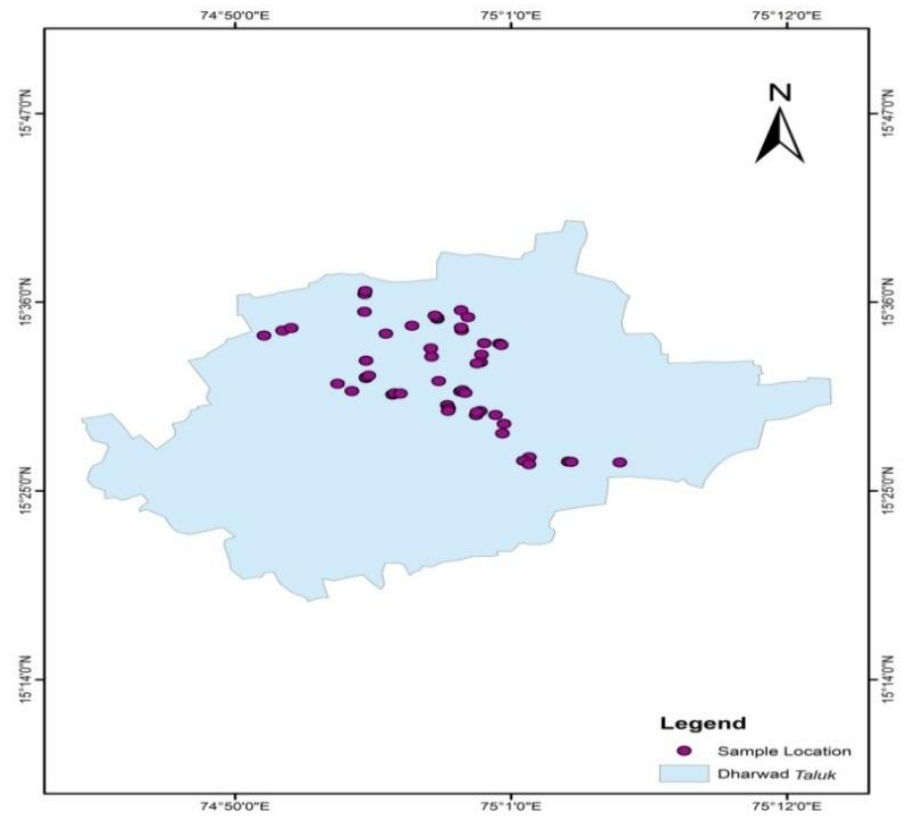




\section{Iron $(\mathrm{Fe})$ uptake}

The iron uptake by soybean plants in below average yield category ranged from 490.71 to $690.60 \mathrm{~g} \mathrm{ha}^{-1}$ with a mean value of $643.28 \mathrm{~g}$ $\mathrm{ha}^{-1}$ and standard deviation of 58.046 (Table 1). In above average yield category it ranged from 718.32 to $874.25 \mathrm{~g} \mathrm{ha}^{-1}$ with a mean value of $795.61 \mathrm{~g} \mathrm{ha}^{-1}$ and standard deviation of 43.949 (Table 1). The mean uptake of iron in below average yield category was found to be lower than above average yield category.

\section{Manganese (Mn) uptake}

The manganese uptake in below average yield category ranged from 91.26 to $140.73 \mathrm{~g} \mathrm{ha}^{-1}$ with a mean value of $118.67 \mathrm{~g} \mathrm{ha}^{-1}$ and standard deviation of 15.288 (Table 1). In above average yield category, it ranged from 104.13 to $162.16 \mathrm{~g} \mathrm{ha}^{-1}$ with a mean value of $134.25 \mathrm{~g} \mathrm{ha}^{-1}$ and standard deviation of 19.552 (Table 1). The manganese taken up by soybean did not vary in both the categories. But the mean uptake of Mn above average yield category was found to be higher (Table 1) than that of below average yield category (Table 1). Pradeep et al., (2006) reported that higher uptake of nutrients is also due to higher dry matter production in above average yield category.

Relationship between soil properties and nutrient status with soybean dry matter production

Among chemical properties of soils, organic carbon content showed significant and positive relationship with dry matter production in both below and above average yield categories (Table 2). Among micro nutrients, available zinc and iron were found to be positively and significantly correlated with dry matter production in both below average and above average yield categories (Table 2).
In conclusion, all micronutrient uptake in above average yield category was found to be higher than that of below average yield category it might be due to the higher nutrient status in the soils of above average yield category

\section{References}

Anonymous. 2015. Annual report of Directorate of Economics and Statistics, Department of Agriculture and Cooperation, Ministry of Agriculture, New Delhi, retrieved from www.agricoop.com

Apeji, S. A. 1988. Pest of Cowpea and Soybean in Nigeria, Federal Department of Pest Control Service, Kaduna.

Awlad, H. M., Chowdhury, M. A. H. and Talukder, N. M. 2003. Effect of sulphur and zinc on nodulation dry matter yield and nutrient content of soybean. Pak. J. Biol. Sci. 6 (5): 461-466.

Bennett, W. F. 1993. Plant nutrient utilization and diagnostic plant symptoms. In: Nutrient deficiencies and toxicities in crop plants. Bennett WF (Ed.) St. Paul, MN: The APS Press, the American Phytopathological Society. pp: 1-7.

Bidari, B. I. 2000. Studies on yield and quality of Byadgi chilli (Capsicum aпnиит L.) in relation to soil properties in transitional zone and part of dry zone of north Karnataka. Ph. D. Thesis, Univ. Agric. Sci., Dharwad. Karnataka (India).

Fageria, N. K. 2007. Soil fertility and plant nutrition research under field conditions: Basic principles and methodology. J. Plant Nutr. 30, 2, 203223.

Fageria, N. K. and Baligar, V. C. 2005. Growth components and zinc recovery efficiency of upland rice genotypes. Pesq. Agropec. Bras. 40, 1211-1215.

Fontes, R. L. F. and Cox, F. R. 1998. Iron 
deficiency and zinc toxicity in soybean grown in nutrient solution with different levels of sulfur. J. Plant Nutr. 21, 8, 1715- 1722.

Fox, T. C. and Guerinot, M. L. 1998. Molecular biology of cation transport in plant. Ann. Rev. Plant Physiol. Plant Mol. Biol. 49, 669-696.

Imsande, J. 1998. Iron, sulfate, and chlorophyll deficiencies: A need for an integrative approach in plant physiology. Physiol. Plant. 103, 139144.

Izaguirre Mayoral M. L. and Sinclair. R. T. 2005. Variation in manganese and iron accumulation among soybean genotypes growing on hydroponic solution of differing manganese and nitrate concentrations. J. Plant Nutr. 28, 521535.

Jagdish, P. and Hajare, T. N. 1992. Performance of two soybean (Glycine max) varieties under different agronomic practices in Vertic Ustocherpts soils of Vidarbha. Indian Agron. J., 37(2): 366-368.

Jagdish, P. and Singh, S. B. 1997. A study on adoption of improved technology in Malwa region. Agric. Sci. Dig., 17: 223-
226.

Mandal, B. Hazra, G. C. and Mandal, L. N. 2000. Soil management influence on zinc desorption for rice and maize nutrition. Soil Sci. Soc. Am. J., 64, 1699-1705.

Popelkova, H. Waman, A. and Yocum, C. 2003. Amino acid sequences and solution structures of manganese stabilizing protein that affected reconstitution of photosynthesis II activity. Photosynthesis Res. 77, 21-34.

Pradeep, R., Dasog, G. S. and Kuligod, V. B. 2006. Nutrient status of some groundnut growing soils of Upper Krishna Command Area, Karnataka. Karnataka J. Agric. Sci., 19(1): 131-133.

Prasad, B. R., Subbarao, A. and Subbarao, I. V. 1982. Preliminary field observation of zinc deficiency in groundnut on coastal sands in Bapatla - Chirala belt. Andhra Agric. J., 29(4): 300-301.

Welch, R. M. 2001. Impact of mineral nutrients in plants on human nutrition on a worldwide scale. Plant NutritionFood Security and Dordrecht, Netherlands. pp: 284-258.

\section{How to cite this article:}

Chandra Sheker, B., B.M. Radder, Vijay Kumar Didal, Badaka Amruth and Arigela Kiran. 2017. Micronutrient ( $\mathrm{Cu}, \mathrm{Zn}, \mathrm{Fe}$ and $\mathrm{Mn}$ ) Uptake in Soybean [Glycine max (L.) Merill] Growing Soils of Dharwad Taluk (Karnataka). Int.J.Curr.Microbiol.App.Sci. 6(7): 397-403. doi: https://doi.org/10.20546/ijcmas.2017.607.047 